\title{
Experiences with Weed Discs and Other Nonchemical Alternatives for Container Weed Control
}

\author{
Calvin Chong
}

\begin{abstract}
Additional INDEX wORDS. nursery, container production, weed control, ornamentals
Summary. The first weed disc (Weed Guard) was introduced to Ontario in the early 1980s. They were made of semirigid plastic similar to $45-\mathrm{rpm}$ records. Small holes allow water to penetrate but weeds germinating on the substrate often grow through them. In the 1990s, we obtained 85\% reduction of container weeds using discs made from geotextile fabric (Mori Guard) or foam (similar to polyfoam used for container winter protection). The foam disc tended to curl upward at the edges, become easily windblown, and tended to partially expose the surface of the container mix. During the past 15 years, we have annually reused the same fabric discs (now unavailable due to high unit cost), and have tested various other weed discs, including several new-generation types and also the Mori Weed Bag. The new-generation discs are fabricated from materials such as fabric (Tex-R Geodisc), pressed peat moss (Biodisc), corrugated cardboard (Corrudisc), and plastic (Enviro LID). Both Tex-R Geodisc and Enviro LID were as effective or better in controlling weeds than weekly hand-weeding, herbicides, or the Mori Guard fabric disc. The Mori Weed Bag, a patented black polyethylene sleeve with prepunched holes fitted around the container like a florist's plant prepared for market, is used effectively and almost exclusively by one Ontario nursery. We also tested two types of insulated blanket covers, which when placed around the ball of above-ground container-grown trees, prevented weed growth during the summer and also protected the root ball against cold during the winter. We introduced the garbage bag sleeve, the ultimate no-weed method for pot-in-pot tree culture, which also reduces water use and frequency of irrigation. Due to factors such as under-performance, insufficient demand, and/or high costs, only certain discs are currently manufactured: Weed Guard, Tex-R Geodisc, Biodisc, and Enviro LID. The Mori Weed Bag is available but not the insulated blankets.
\end{abstract}

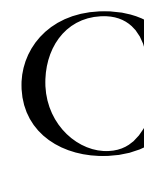

ontainer production is rapidly increasing and represents about $35 \%$ of Canadian-grown nursery stock. Weeds are a major problem in container nurseries because they are costly to remove and they compete with the plants for water and nutrients, thereby reducing growth, quality and saleability (Gilliam et al., 1990; Mervosh, 1999; Roul and Lemay, 2000). Economic losses due to weed infestations on a 6.1-ha (15-acre) container site can cost up to $\$ 100,000$ (J. Langendoen, personal communication).

While U.S. nurseries effectively control weeds in containers with a spectrum of licenced herbicides, Canadian nurseries have few herbicides registered for ornamental use. Canadian nurseries have therefore resorted to different means, primarily hand-weeding in conjunction with weed discs and other nonchemical options (Chong and Purvis, 2000).

Professor, University of Guelph, Department of Plant Agriculture-Vineland (Horticultural Research Institute of Ontario), Vineland Station, Ont., Canada LOR 2E0.

Aspects of this research were supported by Braun Nurseries, Mori Nurseries, Willowbrook Nurseries, and the National Research Council Canada, Industrial Research Assistance Program (IRAP). 
Several herbicides released for container use since the mid-1990s [Ontario Ministry of Agriculture, Food and Rural Affairs (OMAFRA), 2000] have provided variable results, and often require mid-season reapplication. Herbicides may also be phytotoxic (Calkins et al., 1996).

Interests for nonchemical alternatives to container weed control have been renewed due to increasing concerns over contamination of irrigation ponds and the ground water (Mervosh, 1999; Riley, 2002). Waste materials used as mulch for weed control may also help to conserve landfills and counter concerns of environmentalists that weeds will become resistant to herbicides (Mervosh and Abbey, 1999; Smith et al., 1998; Roul and Lemay, 2000).

Since 1984, the Ornamental Nursery Program at the Horticultural Research Institute of Ontario (now part of the University of Guelph) has been conducting applied research dealing with alternative environmentallyfriendly practices, with emphasis on container production (Chong and Hamersma, 1995). This report describes our experiences and observations with weed discs and other nonchemical methods of container weed control.

\section{Weed discs}

The traditional weed disc is round and has a slit to the center so that it can be fitted around the stem of the plant. Desirable characteristics include: it should be easy to apply; lay flat and fit snugly on top of the container substrate; not be easily dislodged or windblown; be permeable to water; not support weed germination and growth on its surface; be available in various sizes; and be durable and cost effective.

In the early 1980s, Connon Nurseries (AVK), Rockton, Ont., Canada, was perhaps the first to introduce the weed disc (Weed Guard) in Canada (Fig. 1A). The disc is made of a semirigid plastic similar to a 45 -rpm record. Small holes over its surface allow penetration of water but also allow weeds germinating in the substrate to grow through them. Weeds also grow through the enlarged oblong-shaped slit, or around the inner edge of the container. Two discs in offset positions provide better control than a single disc, but increases the control cost. Curled or misshapen discs may partially expose the surface of the substrate, allowing more growth of weeds, and discs are more prone to be dislodged or become windblown.

Chong et al. (1989) reported an $85 \%$ reduction of container weeds using discs made of geotextile fabric [1.6- $\mathrm{mm}(1 / 16$ inch) thick (Fig. 1B); Mori Guard; introduced by Mori Nurseries, Niagara-On-The-Lake, Ont., Canada], or foam [3.2-mm (1/8-inch) thick polyfoam (Fig. 1C)]. This foam disc is similar in consistency to that used for winter storage protection and packaging and was introduced by former Astro-Polyfoam Ltd.,
Mississauga, Ont., Canada. The Foam Disc tends to curl upward at the edge and is easily dislodged or windblown, especially if the surface of the substrate is too close to the container $\operatorname{rim}[\leq 1.5$ $\mathrm{cm}$ (0.59 inch)]. The Mori Guard fabric disc fits more snugly and conforms to the uneven surface of the substrate. However, it becomes easily dislodged or windblown when dry. During the middle- to late season, when roots tend to adhere to the disc underside, there is less dislodgment. Weed seeds germinate readily on the fabric and continue to grow unless removed. Despite these drawbacks, it is noteworthy that during the past 15
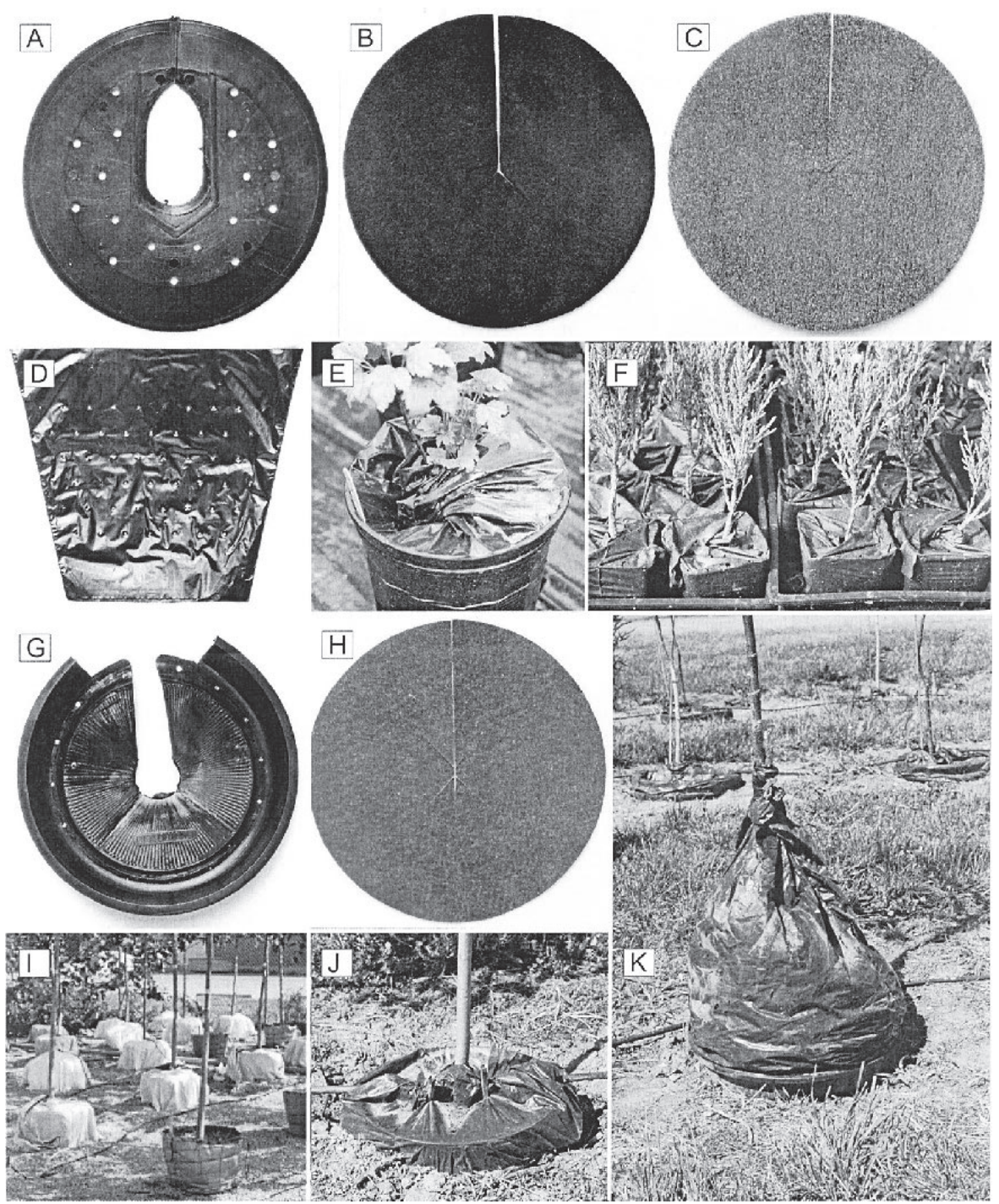

Fig. 1. (A) Weed Guard; (B) Mori Guard; (C) Foam Disc; (D) unopened weed sleeve (Mori Weed Bag); (E) weed sleeve tucked in around \#2 [6-L (1.6-gal)] containers; (F) weed sleeves around small square containers; (G) Enviro LID; (H) Tex-R Geodisc; (I) ball of above-ground containerized shade trees uncovered (front) or covered with insulated capes; $(J)$ pot-in-pot garbage bag sleeve around the inner container with trickle line and emitters tucked in; and (K) garbage bag sleeve pulled upwards and fastened to the trunk. 
Table 1. Description of some new-generation weed control discs.

\begin{tabular}{|c|c|c|c|}
\hline Disc & $\begin{array}{l}\text { Producing } \\
\text { company }^{z}\end{array}$ & Material & Comments \\
\hline Tex-R Geodisc & Texel Inc. & Polyester and viscose fabric & $\begin{array}{l}\text { Easy to apply; conforms well to uneven surface of the substrate but } \\
\text { easily wind-blown if not snug; made with or without copper } \\
\text { coating for preventing surface germination of weeds. }\end{array}$ \\
\hline Biodisc & Premier Tech & Pressed peat moss & $\begin{array}{l}\text { Easy to apply; fits and conforms well to uneven surface of the } \\
\text { substrate; biodegradable - starts to degrade within days after } \\
\text { application; tends to shrink although its effectiveness may last } \\
\text { through a season; weeds germinate easily on the surface. }\end{array}$ \\
\hline Corrudisc & St. Catharines & Corrugated cardboard & $\begin{array}{l}\text { Awkward to apply due to rigidity of the material; initially fits well } \\
\text { but degrades starting after the first irrigation; it loses shape, } \\
\text { separates into layers, and deteriorates rapidly. }\end{array}$ \\
\hline Enviro LID & Enviro LID & Moulded plastic & $\begin{array}{l}\text { Snaps into place around rim of container; substrate should be at } \\
\text { least } 3.8 \mathrm{~cm}(1.50 \text { inch) below top of container or the lid does not } \\
\text { fit properly and may dislodge; expensive. }\end{array}$ \\
\hline
\end{tabular}

zTexel Inc., St-Elzear, Que., Canada; Premier Tech, Riviere-du-Loup, Que., Canada; St. Catharines Corrugated Containers, Allanburg, Ont., Canada; Enviro LID, Langley, B.C., Canada.

years we have annually reused the same fabric discs obtained initially from Mori Nurseries. Unfortunately, these discs are currently unavailable, most likely due to the low demand because of the high unit cost.

Since containers in the same size category may vary slightly in volume or other dimensions, depending on the manufacturer, it is important to ensure a good match between container and disc. A container rim with an inner-facing lip will help to keep the disc in place. Some discs may fit better if the circumference or disc is slightly larger than that of the container. Most discs will not fit properly or stay in place if containers are misshapen or are filled too close to the top. Weed discs are typically not designed for use with multistemmed plants.

\section{Weed sleeve}

In the early 1990s, Mori Nurseries introduced another innovative method of controlling weeds using a special black polyethylene sleeve (Weed Bag) (Fig. 1D). The sleeve is placed around the pot in the same way a florist's plant is prepared for market (Fig. 1E). The upper portion of the sleeve extending beyond the container rim is wrapped loosely around the plant stem and stuck crudely into the surface of the substrate using one's fingers. Water reaches the substrate through small prepunched holes in the sleeve, or through irregular or relatively large spaces around the plant stem when the sleeve unfolds or loosens, as often occurs. Weeds may germinate and grow through the holes but more often grow in the spaces around the stem. Initially, these sleeves were used to prevent weed infestation in small 10.2 -cm-square (4-inch) pots of rooted cuttings (Fig. $1 \mathrm{~F}$ ).

Mori Nurseries encountered mild to severe losses of certain species, most notably cultivars of spirea, after they were grown in Weed Bags and overwintered in unheated, opaque polyethylene houses. Losses seemed to be associated with a) too much water in the substrate, possibly resulting in insufficient aeration; or b) salt buildup from the slow-release fertilizers, possibly resulting from insufficient leaching.

We conducted investigations using sleeves with different configurations in the number and size of holes, various ways of keeping the sleeve in place (loosely wrapped and tucked or tied with twine around the stem), different ways of applying slow-release fertilizer (incorporated into the substrate; top-dressed on the surface of substrate before wrapping the sleeve; or top-dressed on the outer surface of the sleeve after wrapping); and different methods of irrigation (overhead or drip).

Our results (Chong and Shaw, 1993 ) indicated that the substrate remained too wet during most of the growing season. Also the concentration of soluble salts (measured in early winter and early spring the year following planting) seemed sufficiently adequate to cause injury during winter storage, especially in late winter when plants are more susceptible. We recommended fertilizer incorporation at potting, use of more porous substrates, and decrease in frequency and amount of irrigation among other cultural practices, which could be used to mitigate the above effects. Variations in the sleeve per se (size and number of holes and how the sleeve is kept in place) and methods of irrigation had little or no effect on weed or plant growth.

The weed sleeve has been patented by Mori Nurseries and used almost exclusively by this nursery. The sleeve is typically applied at potting and requires extra hand labor. Other producers comment the sleeve is timeconsuming both to apply and to remove. Some garden centers indicate that sleeved container plants are unattractive for display, and that the sleeve is time-consuming to remove and creates a disposal problem. Mori Nurseries counter that this method of weed control, although not perfect, is relatively effective in reducing frequency and amount of hand weeding, and is compatible with their 24.3-ha (60acre) container operation. Furthermore, containers with sleeves removed are cleaner and more attractive at shipping time. Moreover, the new version of the weed sleeve has a seam running along its length, which makes it much easier to remove than earlier versions.

\section{New-generation weed discs}

In the late 1990s, we evaluated several new-generation weed discs (Chong and Purvis, 2000; Table 1). Using liners [forsythia (Forsythia xintermedia) 'Lynwood Gold', potentilla (Potentilla fruticosa) 'Pink Beauty', and weigela (Weigela florida) 'Red Prince'] grown for one season in \#2 [6-L (1.6-gal)] containers, we observed that two of these discs [Enviro LID (Fig. IG) and Tex-R Geodisc with copper-coated underside (Fig. 


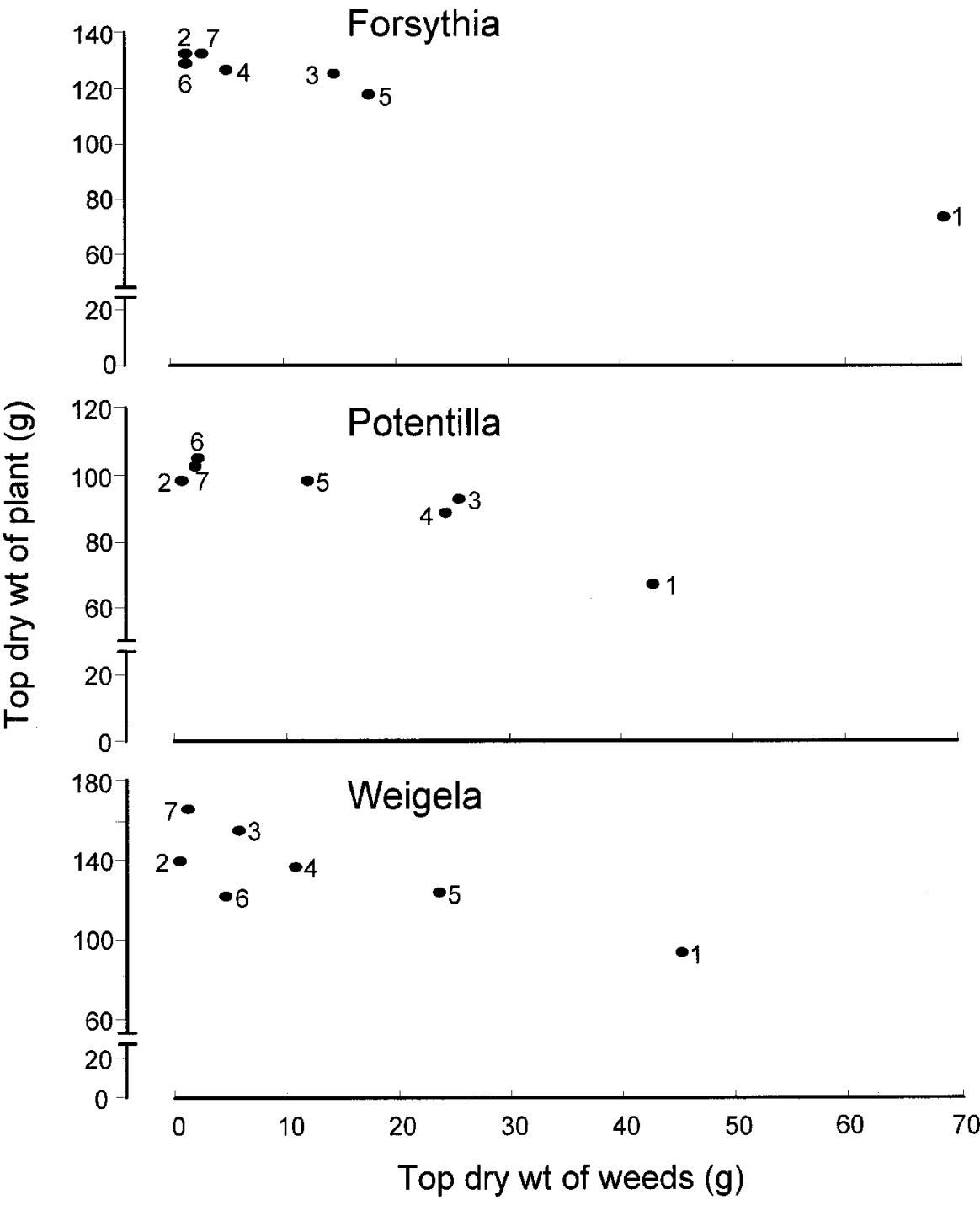

Fig. 2. Relationship between plant growth [end-of-season top dry weight $(1 \mathrm{~g}=0.035$ oz)] and corresponding weed growth in containers with different weed control strategies. Treatments are 1) unweeded control; 2) weekly hand-weeding; 3) napropamide(Devrinol 10G; Stauffer Chemical Co., Richmond, Calif.), and oxadiazon (Ronstar 2G; Rhône-Poulenc Inc., Mississauga, Ont., Canada) herbicides surfaceapplied together at rates of 0.16 and $0.57 \mathrm{gper} \# 2$ [6-L (1.6-gal)] container, respectively, at potting; 4) napropamide and oxadiazon applied at potting plus oxadiazon only 6 weeks later; 5) Mori Guard weed disc; 6) Enviro LID weed disc; and 7) Tex-R Geodiscwith copper-coated underside.

$1 \mathrm{H})$ ] were as effective or better in controlling weeds than weekly handweeding, herbicides, or Mori Guard fabric weed disc (Fig. 2). Furthermore, differences in plant growth among the various weed control treatments for all three species were inversely related with corresponding weed growth in the containers. This result reemphasizes the negative quantitative impact of container weeds which have been shown to reduce plant size by over $50 \%$ (Fretz, 1974).

In a related 2 -year investigation using larger 1 to 3 -year-old plants [spirea (Spiraea Xbumalda) 'Froebelii', the other species), the foliar zinc content also was among the lowest in this treatment. Sichivitsa et al. (1999) reported reduced growth of containergrown petunia (Petunia $\times$ bybrida) due to waste paper mulch.

\section{Insulated blankets}

In the mid-1980s, Braun Nurseries, Hamilton, Ont., Canada, designed and introduced the use of insulated blankets (capes) around the ball of drip-fertigated, above-ground, containerized shade trees to a) protect against cold during winter and b) moderate temperatures and prevent weed growth during the summer (Chong et al., 1990). Once planted and spaced in the nursery, trees could be left undisturbed until marketed.

Using green ash (Fraxinus pennsylvanica var. subintegerrima) as the test species, we evaluated two types of insulated capes [ $160 \times 160 \mathrm{~cm}(63$ inches) (Fig. 1I)]: a) THERMAT, two layers of black geotextile fabric sewn between two layers of opaque 4-mil [0.016-mm (0.004-inch) thick] polyethylene; and b) Polyfoam, one layer of $0.5-\mathrm{cm}(0.20$-inch $)$ thick polyfoam also sewn between two layers of polyethylene. Each of the capes had one slit from the midpoint along one edge to the center to facilitate placement around the tree trunk. The edges were kept in place with gravel.

During the winter, the capes kept the substrates warmer $\left[2{ }^{\circ} \mathrm{C}\left(3.6^{\circ} \mathrm{F}\right)\right.$ extreme minimum temperature, THERMAT; $4^{\circ} \mathrm{C}\left(7.2^{\circ} \mathrm{F}\right)$, Polyfoam ] than a control cover of leaves, i.e., a wire cage with $6 \mathrm{~cm}$ (2.4 inches) of dried leaves around the sides and top of the containerized root system. During the summer, the capes kept the substrates cooler $\left[-3.5^{\circ} \mathrm{C}\left(-6.3{ }^{\circ} \mathrm{F}\right)\right.$ extreme maximum temperature, THERMAT; $-2{ }^{\circ} \mathrm{C} \quad\left(-3.6{ }^{\circ} \mathrm{F}\right)$, Polyfoam] than uncovered containers. Except for a few which grew from the centre of the covers, weeds were eliminated by use of the capes.

\section{Garbage bag sleeve}

With the increase of container shade tree production in the early 1990s, a few producers were using larger plastic weed discs with aboveground containerized trees. Some began to produce trees using the belowground container (pot-in-pot) system. Before this, we conducted pot-in-pot experiments in which we used straw 
mulch for weed control (Murray et al., 1996). The straw mulch was laborintensive to maintain, required reapplication during the same season, and was potentially a haven for rodents.

Based on these considerations and experiences, we designed and successfully used the ultimate no-weed method for pot-in-pot tree culture. We removed the bottom of a large black garbage bag and placed it around and over the inner (growing) container similar to the Mori weed sleeve. The trickle irrigation line and emitter(s) were tucked under the sleeve and held in place over each container by two clothes pins (Fig. 1J).

The garbage bag suppressed weeds effectively, and markedly reduced water use and frequency of irrigation (Chong and Lumis, 2000). Weeds growing around the containers, or in or between the tree rows, had no apparent effect on the trees, and were periodically cut back with a mechanical trimmer. Furthermore, if the garbage bag (sleeve) is made sufficiently long, it can be pulled upwards and fastened to the trunk [perhaps 30 to $50 \mathrm{~cm}$ (11.8 to 19.7 inches) above the substrate] to prevent against possible rodent or animal damage to the lower trunk during the winter (Fig. $1 \mathrm{~K})$.

\section{Conclusion}

Intuitively, it appears that the use of weed discs should be an effective, and economical nonchemical alternative for reducing weeds in container nurseries. But the persistence of weeds remains a challenge. Most weed discs introduced during the past 15 years are no longer being used or sold, largely because they have not performed to expectation. There was unnecessary haste to commercialization with minimal pretesting. Of those we tested, currently available ones include: Weed Guard, Tex-R Geodisc, Biodisc, and Enviro LID. The Mori Weed Bag is also available but not the insulated blankets due to high unit cost and insufficient demand. Some quite novel and innovative examples of weed control discs are: cardboard discs uncoated or coated with wax; and biodegradable pressed peat moss disc impregnated with slow-release fertilizer. These, or other examples discussed above, may have the potential to be improved and reintroduced in the future.

While this presentation is limited to our experiences, there are other innovative alternatives as described in this workshop by Mathers (2002) and by others (Mervosh, 1999; Roul and Lemay, 2000). Undoubtedly other ideas may emerge in the future. Nonchemical alternatives will remain important as long as herbicide use is restricted in areas such as Canada. Herbicide alternatives are becoming more important as other jurisdictions face similar potential restrictions.

\section{Literature cited}

Calkins, J.B., B.T. Swanson, and D.L. Newman. 1996. Weed control strategies for field grown herbaceous perennials. J. Environ. Hort. 14:221-227.

Chong, C. and B. Hamersma. 1995. Environmentally friendly nursery production practices. Comb. Proc. Intl. Plant Prop. Soc. 45:536-537.

Chong, C., B. Hamersma, and P. Braun. 1990. Shade tree production in aboveground wire basket containers. Landscape Trades 12(9):10, 12-14.

Chong, C., B. Hamersma, and D. Ponzo. 1989. In search of the ultimate weed control disc. Hort. Rev. (Ontario) 7(17):811 .

Chong, C. and G.P. Lumis. 2000. Mixtures of paper mill sludge, wood chips, bark, and peat in substrates for pot-in-pot shade tree production. Can. J. Plant Sci. 80:669-675.

Chong, C. and P. Purvis. 2000. Searching for nonchemical alternatives to container weed control. Landscape Trades 22(1):48.
Chong, C. and T. Shaw. 1993. Effects of Mori Weedbags on the container growing regime and performance of nursery crops: A 2-year study. Res. Rpt., Ont. Min. Agr. Food, Hort. Res. Inst. Ont.

Fretz, T. 1974. Evaluation of experimental herbicides on container-grown nursery stock, p. 29-32. In: 1974 Turf and landscape research. Res. Summ. 79. Ohio Agr. Res. Dev. Ctr., Wooster.

Gilliam, C.H., W.J. Foster, J.L. Adrian, and R.L. Schumack. 1990. A survey of weed control costs and strategies in container production nurseries. J. Environ. Hort. 8:133-135.

Mathers, H. 2002. Novel methods of weed control in containers. HortTechnology $13(1): 28-34$

Mervosh, T.L. 1999. Weed patrol. Amer. Nurseryman 190(5):32-38.

Mervosh, T.L. and T.M. Abbey. 1999. Evaluation of fabric discs, mulches and herbicides for preventing weeds in nursery containers. Proc. N.E. Weed Sci. Soc. 53:122.

Murray, C.L., G.P. Lumis, and C. Chong. 1996. Fertilizer method and container size effects on shade trees grown in in-ground containers. Can. J. Plant Sci. 76:507-513.

Ontario Ministry of Agriculture, Food and Rural Affairs. 2000. Nursery and landscape plant production. Publ. 383. Queen's Printer Ont., Toronto.

Riley, M. 2002. Herbicide losses in runoff of containerized-plant-production nurseries. HortTechnology 13(1):16-22.

Roul, I.T. and M.A. Lemay. 2000. Innovations for container weed control. Landscape Trades 23(5):20-21.

Sichivitsa, J.O, C.H. Gilliam and J.H. Edwards. 1999. Recycled waste paper affects nutrient leaching from nursery containers. HortScience 34:824 (abstr.).

Smith, D.R., C.H. Gilliam, J.H. Edwards, J.W. Olive, D.J. Eakes, and J. Williams. 1998. Recycled waste paper as a nonchemical alternative for weed control in container production. J. Environ. Hort. 16:69-75. 